Uniwersytet Warmińsko-Mazurski w Olsztynie

Wydział Prawa i Administracji

DOI: $10.13166 / \mathrm{JMS} / 108951$

Katedra Prawa Administracyjnego i Nauki o Administracji

JOURNAL OF MODERN

romaniuk1@wp.pl

SCIENCE TOM 1/40/2019,

S. $235-251$

\title{
MANAgEMENT AND HUMANITIES \\ AS A MANIFESTATION OF THE QUALITY \\ OF LAW-MAKING IN THE CONTEXT OF THE \\ IMPLEMENTATION OF THE RIGHTS OF WORKERS \\ IN PUBLIC ADMINISTRATION \\ ZARZĄDZANIE HUMANISTYCZNE JAKO PRZEJAW JAKOŚCI TWORZENIA PRAWA W KONTEKŚCIE REALIZACJI PRAW PRACOWNICZYCH W ADMINISTRACJI PUBLICZNEJ
}

\begin{abstract}
Public administration develops and develops instruments to increase its capacity for more effective exercise of member states. This effectiveness must be based on observance of the legal principles where actions, decisions and steps are taken in accordance with the law. In this respect, the key will be to put down the flow of humanistic management, which in its science returns extremely strong attention to any man, in this case administrative work of the public administration. The law is designed to be friendly and, most importantly, understandable for all its recipients. This article is devoted to the role of humanist management, which in a very visible way influences the way services are offered, influencing the quality of their services. The review uses a literature review in accordance with humanistic principles, with the purpose of selecting a studio and organization.
\end{abstract}

\section{STRESZCZENIE}

Administracja publiczna powinna nieustannie się rozwijać i wprowadzać odpowiednie instrumenty, aby zwiększać swoje możliwości w zakresie coraz skuteczniejszego sposobu realizacji zadań publicznych. Ta skuteczność musi być oparta na 
przestrzeganiu zasady legalności, gdzie wszelkie działania, decyzje i kroki byłyby podejmowane zgodnie $\mathrm{z}$ obowiązującymi przepisami prawa. $\mathrm{W}$ tym zakresie kluczowe będzie odniesienie się do nurtu zarządzania humanistycznego, który w swojej nauce zwraca niezwykle silną uwagę na samego człowieka, w tym przypadku pracownika administracji publicznej. Prawo powinno być tak skonstruowane, aby było ono przyjazne i, co najważniejsze, zrozumiałe dla wszystkich jej odbiorców. Artykuł poświęcony jest roli zarządzania humanistycznego, które w sposób coraz bardziej widoczny oddziałuje na sposób tworzenia prawa, przy okazji mocno akcentując poszanowanie praw pracowniczych $\mathrm{w}$ administracji publicznej, wpływając pośrednio również na jakość oferowanych przez pracowników usług. W opracowaniu wykorzystano przegląd literatury dotyczącej zarządzania humanistycznego, uwzględniając przy tym pozycję pracownika i tworzonego prawa w zmieniających się uwarunkowaniach prawnych i organizacyjnych.

KEYWORDS: management, human rights management, administration, law quality, employee rights

SŁOWA KLUCzowe: zarządzanie, zarzadzanie humanistyczne, administracja, jakość prawa, prawa pracownicze

\section{WPROWADZENIE}

Kolejna edycja spotkań poświęconych prawom człowieka skłoniła do refleksji nad ważnym tematem: nad zarządzaniem humanistycznym. Oczywiście nurt ten zostanie zwięźle scharakteryzowany, jednak dużo uwagi autor poświęca na zagadnienia związane z zarządzaniem kadrami w administracji publicznej, a także z jakością tworzonego prawa w warunkach nieustannych wyzwań cywilizacyjnych oraz społecznych. Nie można przy tym zapominać o roli samego człowieka (pracownika), który musi odnaleźć się w świecie rozwoju wszystkich organizacji. To także konieczność zagwarantowania pracownikom przysługujących im praw. Artykuł ma wymiar wielowątkowy, jednak finalnie sprowadza się do implementacji nurtu zarządzania humanistycznego w dyskusję związaną z jakością tworzonego prawa, w kontekście odnalezienia też właściwej pozycji pracownika administracji publicznej. W opracowaniu przyjęto również założenie, że zarządzanie humanistyczne - a w konsekwencji potrzeby i oczekiwania personalne - ma wpływać na jakość tworzonego prawa, które powinno być przyjazne, zrozumiałe i praktycznie wykorzystywane. 


\section{CZYM JEST ZARZĄDZANIE HUMANISTYCZNE?}

Jest to pytanie niezwykle dziś ważne, ale również nieczęsto podnoszone w systemie wartości funkcjonujących organizacji. Zainteresowanie omawianymi aspektami humanistycznego zarządzania dostrzec już można w latach 30. XX w. Wówczas pojawiła się wszechobecna krytyka podejścia do samego człowieka, gdzie dostrzega się ogromne rozczarowanie metodami, które stosowane były w tzw. naukowej organizacji pracy (Kożuch, 2010, s. 14-15). Naukowcy zaczęli koncentrować wtedy swoje zainteresowanie właśnie na człowieku. Tym bardziej że po pierwsze człowiek jest najważniejszym zasobem każdej organizacji, po drugie zaś człowiek jest niewątpliwie najbardziej zmiennym elementem organizacji oraz złożonego systemu zarządzania. Postawa taka pozwoliła zrewidować w sposób oczywisty podejście do zadań i ludzi, którzy tę pracę wykonywali. Zaczęto uwzględniać również inne, dotychczas mało wykorzystywane kryteria poświęcone na ocenę systemu zarządzania. Odstąpiono od ocen tylko i wyłącznie matematycznych, a w ich miejsce zastosowano metody dotyczące działań bardziej elastycznych, poświęconych spełnianiu aspiracji, realizacji planów czy oczekiwań jednostek (Wychowaniec, 2016, s. 110). Dlatego w sposób widoczny przewartościowano pogląd, że człowiek tylko i wyłącznie biernie podporządkowuje się uznanym w danej organizacji regułom i poddaje się przyjętym odgórnie zasadom.

W kolejnych koncepcjach nurt zarządzania humanistycznego poszedł jeszcze dalej, gdyż zaczęto coraz odważniej akcentować indywidualne i osobowościowe kryteria człowieka. Zwrócono również uwagę na kwestię, że zachowania człowieka o charakterze nieracjonalnym z punktu widzenia celów i zadań organizacji - mogą być jak najbardziej w pełni racjonalne i właściwe $\mathrm{z}$ innego poziomu postrzegania. Tym poziomem obserwacji jest punkt widzenia jednostek lub grupy uczestników organizacji, którzy inaczej postrzegają swoją istotną rolę w dynamicznie zmieniających się organizacjach (Koźmiński, Latusek-Jurczak, 2011, s. 64-66). To w konsekwencji stało się impulsem do działań związanych z opracowaniem dość popularnej później koncepcji tzw. gry organizacyjnej, która przyczyniła się do rozpoczęcia prac nad nową filozofią zarządzania, której celem było skoncentrowanie się na uruchomieniu indywidualnego potencjału rozwoju pracownika. 
$\mathrm{W}$ dalszej kolejności zainicjowano prace nad badaniem organizacji, z uwzględnieniem ludzi, którzy wypełniają różne role w systemie takich organizacji. Działania oparte na tej filozofii są niezwykle ważne dla tworzenia nowego spojrzenia na sprawy ułatwiające lepsze zrozumienie człowieka, który musi odnaleźć swoje miejsce w świecie zmieniających się organizacji. Początek XXI w. pokazał, jak bardzo rozwija się humanistyczna perspektywa zarządzania, gdzie widoczne są koncepcje charakteryzujące typową humanizację zarządzania, powodujące charakterystyczny koniec epoki człowieka ekonomicznego. Jednak te dwie kategorie łączące człowieka humanizującego i człowieka ekonomicznego są od siebie zależne i współodpowiedzialne za kształtowanie wzajemnych relacji. O takim aspekcie mówi chociażby B. Kożuch, która uważa, że czysty humanizm i czysty ekonomizm w naukach o zarządzaniu zwyczajnie nie istnieją (Kożuch, 2010, s. 19-20). To pokazuje, że w naukach o zarządzaniu zarządzanie humanistyczne nie daje się tak jednoznacznie oddzielić od zarządzania ekonomicznego. Większość refleksji poświęconych jest jednak zarządzaniu humanistycznemu, które staje się być coraz mocniej akcentowanym nurtem w dogmatyce zajmującej się funkcjonowaniem nowoczesnych organizacji.

Dokonując dalszej analizy związanej z zakresem, w jakim współczesne zarządzanie potrzebuje humanistów, M. Kostera zauważa, że poszukiwanie sensu życia i odnalezienie własnej drogi w organizacji jest rzeczą całkowicie naturalną, gdzie odkrywanie i próba zrozumienia jakże skomplikowanego świata i tym samym świata organizacji powoduje, że to człowiek jest w samym centrum uwagi (Kostera, 2010, s. 15-16). Stąd naturalnym źródłem zainteresowania nurtu humanistycznego są zjawiska związane z człowiekiem, jego miejscem $w$ organizacji oraz pełnieniem przez niego różnych zadań, gdzie humanistyka przyznaje człowiekowi pierwszeństwo dla paradygmatów wskazujących człowieka jako najważniejszego aktora, obdarzonego tzw. mocą sprawczą, niezbędną do realizacji misji stawianych mu na różnych płaszczyznach jego życia. Istotny w tym zakresie staje się wybór adekwatnych celów i metod badawczych przypisanych nurtowi humanistycznemu (Wychowaniec, 2016, s. 113). 
Tabela 1.

Nurt humanistyczny w naukach o zarządzaniu

\begin{tabular}{|c|c|}
\hline Wyszczególnienie & Nurt humanistyczny \\
\hline Główni prekursorzy & $\begin{array}{c}\text { Max Weber } \\
\text { Elton Mayo }\end{array}$ \\
\hline Paradygmaty & $\begin{array}{c}\text { radykalno-humanistyczny } \\
\text { i interpretatywny }\end{array}$ \\
\hline Metodologia & jakościowe studium przypadku \\
\hline Główny przedmiot badań & $\begin{array}{c}\text { organizacje oraz zarządzanie widoczne } \\
\text { z perspektywy ludzkiej }\end{array}$ \\
\hline Cel badań & $\begin{array}{c}\text { zwiększenie dobrobytu ludzi w organizacjach; } \\
\text { poznanie organizacji i mechanizmów } \\
\text { zarządzania z pespektywy człowieka }\end{array}$ \\
\hline
\end{tabular}

Źródło: Opracowanie własne na podstawie: J. Kociatkiewicz, M. Kostera (2013). Zarządzanie humanistyczne. Zarys programu, „Problemy Zarządzania”, Vol. 11, nr 4 (44), s. 9-13.

Sama humanistyka nie dąży w swoim zakresie do uspójnienia w formie jednego dominującego paradygmatu (humanistyczny, ekonomiczny), jednak jej nauka nieustannie zmierza do dostarczania odbiorcom wciąż nowych perspektyw. To pokazuje, jak bardzo dynamicznie zmienia się postrzeganie humanistyki w nauce zarządzania. Również walidacja spostrzeżeń samej humanistyki wykracza poza ramy tworzenia nauki. Sam J. Parker zauważył, że zarządzanie humanistyczne jest procesem uruchamianym i kontrolowanym przez czytelnika (Parker, 2008, s. 92-94), gdzie przy każdym zetknięciu się z testem humanistycznym każdy nowy czytelnik może uzyskać inny kontekst znaczeniowy czy konsekwencje poznawcze (Prawelska-Skrzypek, Lenartowicz, 2013, s. 48-49).

\section{Pracownicy Administracji PUBliczNeJ STRATEGICZNYM ZASOBEM ORGANIZACJI}

Pojawiające się w XVIII w. ogromne zmiany w okresie rewolucji przemysłowej w Anglii udoskonaliły proces produkcji. Dopiero na przełomie wieków XIX i XX został dostrzeżony niezwykle ważny aspekt związany z czynnikiem ludzkim, wpływającym na rozwój różnych przedsiębiorstw. 
Dlatego pojawił się pogląd, który jest bardzo mocno akcentowany w rozwoju współczesnych organizacji, że najcenniejszym zasobem każdej organizacji w XIX w. były nie tylko urządzenia, ale również - czy przede wszystkim - ludzie wykorzystujący właśnie takie maszyny. Dużą uwagę zwrócono na pracowników umysłowych, którzy, odpowiednio przygotowani, byli w stanie wpływać na zwiększenie wydajności pracy, gdzie dbanie o czynnik ludzki wraz z poszukiwaniem odpowiednich pracowników stało się fundamentalnym celem każdego przedsiębiorstwa (Drucker, 2000, s. 140-142).

W oparciu o teorię A. Smitha, dla prowadzenia działalności gospodarczej zawsze niezbędnym zasobem jest czynnik ludzki. To samo dzieje się w przypadku funkcjonowania każdej organizacji, tym bardziej administracji publicznej, gdzie zasobem są ludzie. Ponadto w literaturze przedmiotu można odnaleźć różnorodne sposoby umiejscowienia człowieka w świecie organizacji, który utożsamiany jest jako zasób oraz kapitał ludzki. W głównej mierze przytoczone oba pojęcia dotyczą tego samego, czyli elementu ludzkiego pełniącego różne funkcje w organizacji. Dla przykładu S. Domański łączy te dwa znaczenia pojęciowe w jedną całość. Według tego autora, czynnik ludzki w każdej organizacji to odpowiedni zasób wiedzy, określone umiejętności, zdrowie i odpowiednia energia potrzebna do realizacji zadań. To także zasób osobowy, który trzeba umiejętnie i precyzyjnie pielęgnować, stwarzając jednocześnie możliwość pracownikom do inwestowania w ich rozwój merytoryczny i zawodowy. Czynnik ludzki to również wskaźnik możliwości organizacyjnych i budowanie kreatywności jednostki i grupy ludzi. Warto zaznaczyć, że jest on niezbywalną częścią swojego posiadacza, co pokazuje, iż jest on trwale z nim związany (Domański, 1993, s. 18-19). Czasami pojawiają się nieznaczne różnice $\mathrm{w}$ sposobie definiowania przytaczanych kategorii pojęciowych, gdzie np. kapitał ludzki odróżniany jest od kapitału rzeczowego. Różnicą jest to, że kapitał ludzki nie może zmienić właściciela, gdyż nie podlega obrotowi. Również $\mathrm{w}$ porównaniu $\mathrm{z}$ innymi zasobami organizacji, ludzie pomnażają swoją wartość, natomiast w tym samym czasie inne zasoby w trakcie codziennego wykorzystywania zwyczajnie się deprecjonują (Górecka, 2009, s. 566-568).

Samo znaczenie kapitału ludzkiego wskazuje niebywałą rolę pracowników $\mathrm{w}$ nieustannym procesie funkcjonowania i rozwoju administracji publicznej 
i każdej organizacji. Ludzie w niej zatrudnieni, a także wykorzystywana przez nich wiedza i posiadane umiejętności, wpływają pozytywnie na wykorzystanie innych, równie ważnych, zasobów organizacji. Można też zauważyć, że wpływ zasobu ludzkiego na sytuację w podmiotach administracji publicznej można rozpatrywać w poniższych skalach (Ludwiczyński, Król, 2008, s. 109-113):

- skala makro, gdzie wskazuje się duży wpływ wielkości i struktury kapitału ludzkiego w organizacji wpływający na rozwój społeczeństwa, a nawet ludzkości; duże znaczenie w tym obszarze zajmuje gospodarka oparta na innowacyjności wraz z odpowiednią infrastrukturą techniczną, organizacyjną oraz socjalną;

- skala indywidualna, która duży nacisk kładzie na inwestowanie w samych pracowników administracji publicznej, gdzie kumuluje się jednocześnie wiele nakładów, do których zaliczyć można odpowiednią edukację, szkolenia, kursy oraz nabyte doświadczenie (Dobija, 2003, s. 18-19);

- skala zespołu, gdzie odczuć można wpływ poszczególnych członków zespołu na realizację zaplanowanych zadań; w tym działaniu właściwie zarządzany kapitał ludzki w administracji publicznej jest ściśle skorelowany z poprawnym kierowaniem zespołem osobowym.

W świadomie zarządzanych organizacjach największy wpływ na zachodzące pozytywne zmiany zawsze mają pracownicy. Te aspekty powodują, że im większe zaangażowanie pracowników w realizację celów organizacji, tym bardziej jest ona dysponowana do dynamiczniejszego rozwoju. Jednak człowiek bez odpowiedniego zaplecza prawno-organizacyjnego nie jest w stanie w pełni wykorzystać swoich możliwości. Stąd inwestycje w kapitał osobowy w administracji publicznej, będący jej strategicznym zasobem, można posegregować według poniższych zamierzeń:

- inwestowanie w strategię rozwoju personalnego;

- inwestowanie w szkolenia pracownicze, które wpływają na podnoszenie kompetencji urzędniczej;

- inwestowanie w utrzymywanie i zwiększanie poziomu wiedzy w organizacji, za pomocą której organizacja osiąga zaplanowane cele; 
- inwestowanie w tzw. marketing personalny, którego główną cechą jest przyciągnięcie do organizacji utalentowanych ludzi;

- inwestowanie w politykę retencyjną, która ma niebywale duży wpływ na utrzymanie pracowników, popartą zwiększeniem zaufania i lojalnością w stosunku do swojej organizacji (ten sposób inwestowania w administracji publicznej nie zawsze jest wykorzystywany);

- inwestowanie w jakość oferowanych przez pracodawcę warunków pracy, co przyczynia się do ograniczenia szkodliwych dla zdrowia czynników;

- inwestowanie w kulturę organizacyjną (Lipka, 2010, s. 129-158).

Należy także zaznaczyć, że właściwe kierowanie zasobami kadrowymi i inwestowanie w pracowników administracji publicznej ma wpływ na sposób kreowania jakości oferowanych usług. Pośrednio również działania takie wpływają na sposób kreowania prawa, które powinno być przyjazne oraz zrozumiałe zarówno dla urzędników publicznych, jak i dla samych obywateli. Od kilku lat obserwujemy dosyć dużą dynamikę zmian w obowiązującym prawie, szczególnie w kontekście prawa administracyjnego, będącego niewątpliwie jedną z ważniejszych gałęzi prawa, które wpływa na kształt relacji łączących obywatela $z$ daną instytucją publiczną. Obok ekonomicznych aspektów realizacji polityki inwestowania w kapitał osobowy w administracji publicznej, można dostrzec również zmniejszenie się tzw. luki kompetencyjnej. Ma to kilka istotnych wymiarów. Po pierwsze, praca w odpowiednim zespole, w którym każdy z jej członków posiada odpowiedni zasób wiedzy, przyczynia się do realizacji zaplanowanych zadań, gdzie praca taka jest bardziej efektywna. Po drugie, odpowiednio kierowany zespół pracowniczy oraz właściwie koordynowany system motywowania pracowników najczęściej przynosi widoczne efekty związane przede wszystkim ze zwiększeniem elastyczności w sytuacji pojawiających się problemów. Po trzecie, inwestowanie w kapitał ludzki wpływa pozytywnie na zmniejszenie kosztów funkcjonowania administracji publicznej, przyczynia się do wzrostu innowacyjności, wykorzystania nowoczesnych narzędzi komunikacji elektronicznych. Czynniki te jednoznacznie wskazują, że wybór odpowiednich pracowników, a co za tym idzie: i sposób kierowania nimi przez zarządzających - przyczyniają się do budowy silnych podstaw dla dobrze funkcjonującej administracji publicznej. 
Ponadto zarządzający, którzy odpowiedzialnie podchodzą do systemu zarządzania ludźmi w sektorze publicznym, muszą nieustannie dbać o swoich podwładnych, co przedkłada się pośrednio na stan troski o własną organizację. Kierując pracownikami, muszą oni stworzyć adekwatny do potrzeb system motywacji, dobre warunki pracy, przyczynić się do stworzenia przyjaznych stosunków międzyludzkich panujących w zespole oraz przestrzegać przyjętych reguł postępowania. Kiedy wystąpią te wszystkie środki, pracownicy będą chętniej się rozwijali i, co najważniejsze, zdobywali niezwykle potrzebne do wykonywanych obowiązków doświadczenie. Stworzenie uniwersalnych reguł zarządzania kapitałem ludzkim w administracji publicznej, niestety, nie jest jednak możliwe. Podyktowane jest to zmiennością i różnorodnością organizacji oraz warunków je otaczających. Stąd właściwe skoncentrowanie się zarządzających na rozwoju potencjału każdego indywidualnie pracownika stanowi fundamentalny czynnik budujący trwałość, autorytet i rozwój instytucji administracji publicznej (Litwin, 2010).

Zarządzający muszą również przestrzegać, podobnie jak i sami pracownicy, obowiązującego prawa. Im prawo jest lepiej przygotowane, tym sposób jego zastosowania jest zdecydowanie lepszy. Stąd jakość tworzonego dla sektora publicznego prawa musi być nieustannie podwyższana. Niezwykle ważne w tym zakresie są przepisy ustawy z dnia 21 listopada 2008 r. o pracownikach samorządowych oraz o służbie cywilnej. Na podstawie tych regulacji prawnych pracownicy zatrudnieni w szeroko rozumianej administracji publicznej posiadają zakresy praw i obowiązków, które muszą bezwzględnie przestrzegać. Zaliczyć do nich można m.in.:

- dbałość o wykonywanie zadań publicznych oraz o środki publiczne, $\mathrm{z}$ uwzględnieniem przede wszystkim interesu publicznego oraz indywidualnych interesów obywateli;

- przestrzeganie Konstytucji Rzeczypospolitej Polskiej oraz innych regulacji prawych;

- wykonywanie zadań sumiennie, sprawnie i bezstronnie;

- dochowanie tajemnicy ustawowo chronionej;

- zachowanie uprzejmości i życzliwości w kontaktach z obywatelami, zwierzchnikami, podwładnymi oraz współpracownikami;

- zachowanie się z godnością w miejscu pracy i poza nim; 
- stałe podnoszenie umiejętności i kwalifikacji zawodowych;

- sumienne i staranne wykonywanie poleceń przełożonego (ustawa o pracownikach samorządowych oraz ustawa o służbie cywilnej).

Te działania pokazują ewidentnie, że dobrze skonstruowane prawo to prawo oparte na najważniejszych wartościach, które w każdej organizacji i każdym społeczeństwie muszą być pielęgnowane i w świadomości ludzkiej utrwalane.

\section{Kierowanie ludźmi W ADMinistracji PUBLICZNEJ}

W ramach kierowania ludźmi w administracji publicznej, zarządzający dysponują różnymi metodami i technikami oddziaływania na swoich podwładnych, gdzie ich uwaga koncentruje się na realizacji zaplanowanych celów i zadań. Co więcej, dużą rolę w sposobie oddziaływania zarządzających na pracowników odgrywa sposób podejmowania decyzji oraz możliwość włączenia ludzi w ważne sprawy organizacji. Kierujący instytucjami publicznymi muszą mieć również świadomość, że współczesna nauka i prawo daje im możliwość zastosowania wielu stylów kierowania, do których zaliczyć można styl autokratyczny, styl demokratyczny oraz styl nieingerujący (Koźmiński, 2007, s. 424-425).

Styl autokratyczny opiera się na założeniu, że większość pracowników uchyla się od wykonywania zadań i powierzonych obowiązków i dąży do minimalizacji swojego wysiłku na rzecz pracy. Zaletami tego stylu jest m.in. pełna kontrola nad całością zadań, krótki czas na podjęcie decyzji, zachęcanie do wykorzystania rezerwowych zasobów pracy. Natomiast najczęściej spotykanymi wadami są: niewykorzystanie w pełni wiedzy pracowników, hamowanie inicjatyw pracowników, stosowanie stałego nadzoru nad realizacją powierzonych pracownikom zadań.

Styl demokratyczny skupiony jest na założeniu, że pracownicy dbają o dobry wizerunek organizacji oraz chętnie angażują się w sprawy swojego miejsca pracy. W sytuacji pojawiających się problemów starają się je rozwiązać, angażując swoją wiedzę i umiejętności. Także cele organizacji uznają za cele własne, co świadczy o pełnej identyfikacji ze swoim miejscem pracy. Zaletami tego stylu może być integracja grup pracowniczych czy widoczny 
wzrost kreatywności i innowacyjności ludzi. Wadą, niestety, może być zbyt długi okres podejmowania decyzji.

Ostatni z przytoczonych stylów - styl nieingerujący - charakteryzuje się tym, że pracownicy posiadają dużą niezależność i swobodę w podejmowaniu decyzji. Obecność tego stylu można zauważyć w relacjach koleżeńskich łączących pracownika z kierownikiem. Zarządzający widzą swoją rolę w kształtowaniu budowy zaufania do organizacji. Wzmacniają przy okazji poczucie integracji pracownika ze swoją instytucją. Kierownicy takiego stylu nie są skłonni do poświęcenia własnych ludzi dla osiągnięcia założonych celów organizacji, co pokazuje, że pracownicy stanowią dla niego istotną wartość (Koźmiński, 2007, s. 425-428).

Powyższe style wskazują sposoby wpływania zarządzających na podległych im pracowników. Każdy z nich ma zalety oraz wady. Nie istnieje uniwersalny styl zarządzania ludźmi, który mógłby sprawdzić się w każdych warunkach. To powoduje konieczność poszukiwań własnych, indywidualnych sposobów kierowania ludźmi. Oczywiście, systemy te uzależnione są w dużej mierze od samych liderów organizacji, ich cech osobowościowych, przygotowania merytorycznego oraz umiejętności podejmowania - często trudnych - decyzji.

Odpowiednie zarządzanie (kierowanie) zespołem ludzi w administracji publicznej jest nieustannie trwającym procesem, gdzie dużo czasu powinno się poświęcać na zrozumienie pracowników; należy także wskazać ich rolę w organizacji. Bez takiego psychologicznego podejścia nie da się w pełni prawidłowo zarządzać grupą pracowników. Stąd dobry zarządzający w administracji publicznej powinien nie tylko uczyć podległych sobie pracowników, ale również - czy przede wszystkim - powinien nieustannie podnosić swoje umiejętności i kwalifikacje. Nie od dziś wiadomo, że inwestowanie w siebie, jako najcenniejszy zasób organizacji, jest inwestowaniem w siebie i w przyszłość całej organizacji. Odpowiedni kierownicy organizacji muszą ponadto znać potrzeby i oczekiwania pracowników. Ta wiedza jest z kolei niezbędna do efektywnego wdrożenia właściwego procesu zarządzania personelem. Nie można tutaj również zapominać o fakcie, że efektywność zarządzania zasobami kadrowymi w podmiotach administracji publicznej uzależniona jest także od środowiska, poziomu rozwoju 
cywilizacyjnego kraju, posiadanych zasobów czy samych pracowników. To też wpływ odpowiedniego systemu motywacyjnego, który również odgrywa kluczową rolę w zarządzaniu ludźmi. Na uwagę zasługuje także stosowany odpowiedni system komunikacji panujący w organizacji, jednak musi być on dostosowany indywidualnie do specyfiki danego podmiotu administracji publicznej. Omawiane mechanizmy systemu kierowania ludźmi wskazują, że nie ma jednej recepty w systemie zarządzania ludźmi, gdyż jest to proces uzależniony od różnorodnych czynników, nie zawsze zależnych od samej organizacji. Wskazane powyżej teorie są jedynie małym poglądowym obrazem, że można podejmować różne decyzje, które powinny być dostosowane do potrzeb konkretnej organizacji.

Schemat 1 .

Cykl zasobów ludzkich - model dopasowania kadrowego

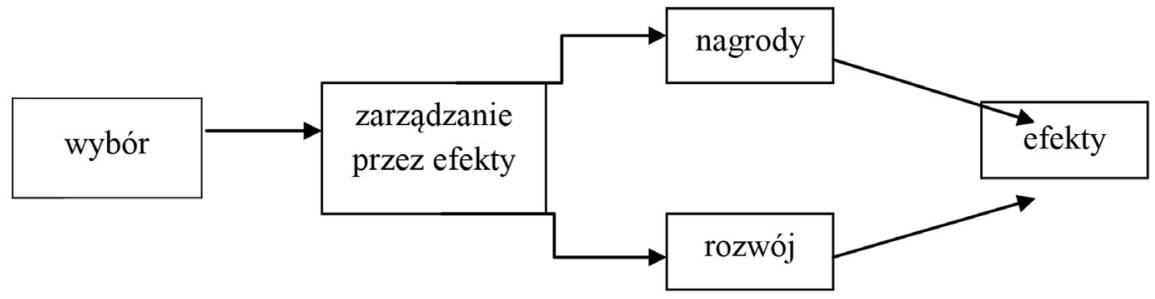

Źródło: Opracowanie własne za: M. Armstrong (2005). Zarządzanie zasobami ludzkimi, Kraków: Oficyna Ekonomiczna, s. 46.

Trzeba też zauważyć, że niektórzy przedstawiciele reprezentujący szkołę Michigan (Fomburn, Tichy, Devana) uważali, iż „systemy zasobów ludzkich oraz strukturę organizacji trzeba zarządzać w sposób zgodny ze strategią organizacji (...)” (Fombrun, Tichy, Devana, 1984). Uznali oni również, że istnieje pewna sekwencja ogólnych procesów lub funkcji obecnych w każdej organizacji, którą nazwali cyklem zasobów ludzkich. Do ważnych elementów tego procesu można zaliczyć:

- wybór - będący dopasowaniem możliwych zasobów osobowych do wolnych stanowisk pracy;

- ocenę - charakteryzującą się wprowadzeniem takiego systemu zarządzania, przekładającego się na osiągnięte efekty i rezultaty; 
- nagrody - stanowiące jedno z najrzadziej wykorzystywanych w administracji publicznej narzędzi, powodujących niewątpliwie polepszenie warunków funkcjonowania organizacji;

- rozwój - którego celem jest nieustanne podnoszenie kompetencji pracowników, co w przyszłości zapewne spowoduje wzrost jakości oferowanych usług.

Również K. Legge zauważyła zależność, że polityka zasobów ludzkich w organizacji, w tym w podmiotach administracji publicznej, powinna być kompatybilna z przyjętą strategią planowania w celu wzmocnienia właściwej kultury organizacyjnej. Autorka zauważa również, że zasoby ludzkie same w sobie stanowią wartość przewagi konkurencyjnej nad innymi podmiotami, tylko że sektor publiczny nie jest nastawiony na realną konkurencję. Przyjęcie odpowiedniej strategii zatrudnienia w administracji publicznej ma na celu zwiększenie jakości świadczonych usług, dzięki czemu poziom satysfakcji obywateli może wzrastać. W tym zakresie zasoby osobowe można wykorzystać za pomocą stworzenia spójnych założeń do takiej polityki, która kładzie duży nacisk na odpowiednie zaangażowanie pracowników, możliwe do osiągnięcia, wykorzystując stosowane instrumenty motywacyjne i kontrolne (Legge, 1989).

\section{WPEYW ZARZADZANIA HUMANISTYCZNEGO NA JAKOŚĆ STANOWIONEGO PRAWA}

Trzeba również zaznaczyć, że funkcjonuje dość powszechny pogląd, iż kryzys związany z tworzeniem prawa w Polsce można rozwiązać za pomocą wykorzystania środków o charakterze technicznym, gdzie należałoby udoskonalić procedury oraz przepisy. Niektórzy uważają nawet, że można stworzyć nowe regulacje prawne związane $z$ utworzeniem nowych zasad tworzenia technik prawodawczych. Jednak wydaje się za zasadne podjąć inny ważny aspekt tej sytuacji. Być może uwidocznił się problem niskiej jakości tworzonego prawa lub nastąpił koniec etosu obywatelskiego. Dla wskazania istoty zagadnienia warto odnieść się do odróżnienia poczynionego przez M. Krygiera, według którego istnieją dwie postawy, którym nadał miano: instytucjonalnego optymizmu i kulturowego pesymizmu. Instytucjonalni optymiści uważają, 
że dla dokonanych zmian wystarczy przejąć dobre i z powodzeniem realizujące swoje zadania instytucje (np. Rzecznik Praw Obywatelskich). Niestety, problem związany z dobrym prawem w ujęciu optymistów jest dylematem czysto technicznym. Natomiast w przypadku osób reprezentujących kulturowy pesymizm nie ma możliwości zmian prawa tam, gdzie nie można dbać o jakość tworzonego prawa i nie można tego stanu zmienić (Krygier, 2005).

Jednak autor niniejszego opracowania jest zdania, że w dużym stopniu jakość tworzonego prawa uzależniona jest od oczekiwań społecznych i świadomości rządzących, że to obywatele finalnie są odbiorcą nowego prawa. Powyższe podejście ma swoje pełne uzasadnienie w przypadku wprowadzenia takich zmian prawnych, które wyjdą naprzeciw oczekiwaniom społecznym. W tym względzie nurt zarządzania humanistycznego, koncentrując swoją uwagę na człowieku, na jego potrzebach, jego możliwościach czy oczekiwaniach, powinien odegrać jedną z kluczowych ról związanych z tworzeniem prawa, a co za tym idzie: i podwyższaniem jego jakości, aby stało się ono przyjazne i, co najważniejsze, w pełni społecznie zrozumiałe.

Co więcej, nieustanne zmiany organizacyjne czy też sukcesywne zmiany w systemie zarządzania publicznego, przyczyniają się do przyjęcia prostego założenia, że prawo powinno być dostosowane do potrzeb rynkowych, organizacyjnych oraz społecznych. Dostrzegamy tutaj nieustanną obecność globalizmu we wszystkich obszarach życia. Dlatego wciąż, czy przede wszystkim, prawo musi być do tych zmian dostosowane i ujednolicane. Nie jest to zadanie proste, jednak, tak jak w przypadku ewolucji człowieka nastąpiły radykalne zmiany, tak i w przypadku zmian w prawie, widocznych szczególnie po 1989 r. - te zmiany są nieustannie dokonywane.

W zarządzaniu humanistycznym zawsze na pierwszym miejscu jest człowiek i jego wszelka działalność oraz aktywność, która skoncentrowana jest na jakimś konkretnie wyznaczonym celu, zazwyczaj opartym na pewnych wartościach. Nauki o zarządzaniu skupione są w dużej mierze na podejściu analitycznym, wskazując przy tym wartości (pragnienia), cele oraz potrzeby człowieka. W tym duchu potrzebą jest podnoszenie jakości prawa, wpływającego na podejście osoby do obowiązków, misji społecznej czy pełnionych w społeczeństwie ról. To determinuje słuszne przekonanie, że odpowiednia jakość prawa jest wyznacznikiem rozwoju i funkcjonowania demokratycz- 
nego państwa prawa. Dlatego trzeba nieustannie dążyć do sytuacji, aby na każdym szczeblu funkcjonowania państwa i zarządzania nim był obecny pogląd, że dobrze funkcjonująca administracja publiczna to dobre, przyjazne i zdrowe prawo, które będzie dostosowywało swoje przepisy do koniecznych zmian. Natomiast ludzie pracujący w administracji publicznej, odpowiednio zarządzani i motywowani, będą wzorem dobrych praktyk postępowania i etycznego przestrzegania prawa, co w sposób naturalny wpłynie na wizerunek instytucji.

\section{Podsumowanie}

Administracja publiczna powinna nieustannie dążyć do rozwoju, a także wprowadzać takie mechanizmy zarządcze, aby zwiększać swoje możliwości w zakresie coraz skuteczniejszego sposobu realizacji zadań publicznych. Ta zasada, skutkująca funkcjonowaniem przyjaznej administracji publicznej, musi być oparta na realizacji niezwykle ważnej innej reguły, jaką jest zasada legalności. Polega ona na tym, że wszystkie kroki przedsiębrane przez podmioty sektora publicznego powinny być decyzjami podejmowanymi zgodnie z obowiązującymi przepisami prawa.

Wyzwaniem dla osób, które w organizacjach odpowiadają za wdrażanie, realizację i zarządzanie polityki personalnej, jest stworzenie odpowiedniej kultury organizacyjnej. To również stworzenie prawidłowych struktur kompetencyjnych i merytorycznych, które oparte są na silnych podstawach związanych z obowiązkiem przestrzegania obowiązującego prawa. W takich okolicznościach pracownicy zatrudnieni w sektorze publicznym muszą jednocześnie podnosić swoje umiejętności, dające szansę rozwoju zawodowego, osobistego i również stwarzające realne możliwości na zapewnienie satysfakcji ze swojej misji. Jeżeli te wszystkie czynniki uda się osiągnąć i wspólnie połączyć, wówczas nadrzędną wartością stanie się wysoki poziom zadowolenia klientów (obywateli), będących bezpośrednim odbiorcą oferowanych usług publicznych. Trzeba też pamiętać o stworzeniu dla pracowników odpowiedniego systemu motywacyjnego, który musi być skierowany na wytworzenie u nich projakościowych zachowań, które wpłyną pozytywnie na ich oczekiwania, nie zapominając przy tym o przyjaźni z prawem i nieustannym dbaniu o jego jakość. 


\section{Literatura}

Armstrong, M. (2005). Zarządzanie zasobami ludzkimi, Kraków: Oficyna Ekonomiczna. ISBN 8389355884.

Armstrong, M. (2011). Zarządzanie ludźmi: praktyczny przewodnik dla menedżerów liniowych, Poznań: Dom Wydawniczy REBIS. ISBN 9788373017245.

Dobija, D. (2003). Pomiar i sprawozdawczość kapitału intelektualnego przedsiębiorstwa, Warszawa: Wydawnictwo Wyższej Szkoły Przedsiębiorczości i Zarządzania. ISBN 8389437082.

Domański, S.R. (1993). Kapitał ludzki i wzrost gospodarczy, Warszawa: Wydawnictwo Naukowe PWN. ISBN 8301106476.

Drucker, P.F. (2000). Zarzadzanie w XXI wieku - wyzwania, Warszawa: New Media. ISBN 9788361040842.

Fombrun, C.J., Tichy, N.M., Devana, M.A. (1984). Strategic Human Resource Management, New York: Wiley. ISBN 9780471810797.

Górecka, K. (2009). Kompetencje a kapitał ludzki i intelektualny. W: M. Gawrońska-Garstka (red.),Edukacja dla bezpieczeństwa. Bezpieczeństwo intelektualne Polaków, Poznań: Wydawnictwo Wyższej Szkoły Bezpieczeństwa. ISBN 9788361304159.

Kociatkiewicz, J., Kostera, M. (2013). Zarzadzanie humanistyczne. Zarys programu, „Problemy Zarządzania”, Vol. 11, nr 4 (44). ISSN 1644-9584.

Kostera, M. (2010). Organizacja $i$ archetypy, Warszawa: Wolters Kluwer. ISBN 9788375267549 .

Koźmiński, A.K. (2007). Zarządzanie. Teoria i praktyka, Warszawa: Wydawnictwo PWN. ISBN 8301141557.

Koźmiński, A.K., Latusek-Jurczak, D. (2011). Rozwój teorii organizacji, Warszawa: Wydawnictwo Wolters Kluwer Polska. ISBN 9788326412226.

Kożuch, B. (2010). Współczesny humanizm organizacyjny. Zarys problematyki. W: T. Wawak (red.), Komunikacja i jakość w zarządzaniu, t. 1, Kraków: Wydawnictwo Uniwersytetu Jagiellońskiego. ISBN 9788323329350.

Krygier, M. (2005). Civil Passions, Melbourne: Black Inc. ISBN 0975076981.

Legge, K. (1989). Human resource management: a critical analysis. W: New Perspectives In Human Resource Management, J. Story (red.), London: Routledge. ISBN 978-1861525086.

Lipka, A. (2010). Inwestycje w kapitał ludzki organizacji w okresie koniunktury i dekoniunktury, Warszawa: Wolters Kluwer Polska. ISBN 9788375267259. 
Litwin, J. (2010). Okresowe oceny pracownicze. W: Golnau W. (red.), Zarzadzanie zasobami ludzkimi, Warszawa: CeDeWu. ISBN 9788375560244.

Ludwiczyński, A., Król, H. (2008). Zarządzanie zasobami ludzkimi, tworzenie kapitatu ludzkiego organizacji, Warszawa: Wydawnictwo Naukowe PWN. ISBN 9788301148133.

Parker, J. (2008). What Have the Humanities to Offer 21st-Century Europe? Reflections of a note taker, „Arts and Humanities in Higher Education”, (7), 83-96. ISSN 1474-0222.

Prawelska-Skrzypek, G., Lenartowicz, M. ( 2013). Badanie organizacji i zarzadzania na gruncie humanistyki, „Problemy Zarządzania”, Vol. 11, nr 4 (44). ISSN 1644-9584.

Wychowaniec, W. (2016). Humanistyka $w$ zarzadzaniu na przykładzie koncepcji zarządzania wiekiem, „Acta Universitatis Lodziensis - Folia Iuridica”, nr 4(324) 2016. ISSN 2450-2782.

\section{Netografia}

http://dx.doi.org/10.1177/1474022207080851 (dostęp: 9 maja 2017 r.).

\section{Akty prawne}

Ustawa z 21 listopada 2008 r. o pracownikach samorządowych (t.j. Dz.U. z 2014 r. poz. 1202 ze zm.).

Ustawa z dnia 21 listopada 2008 r. o służbie cywilnej (t.j. Dz.U. z 2016 r. poz. 1345 ze zm.). 
